\title{
Pengaruh Kinerja Keuangan, Kebijakan Dividen, Dan Kepemilikan Manajerial Terhadap Nilai Perusahaan
}

\author{
Tutik Alawiyah $^{1}$, Kartika Hendra Titisari ${ }^{2 *}$, Yuli Chomsatu ${ }^{3}$ \\ 1,2,3) Universitas Islam Batik Surakarta \\ tutikalawiyah1011@gmail.com, kartikatitisari@gmail.com, you.lichoms@gmail.com
}

*Penulis Korespondensi

$\begin{array}{ll}\text { Diajukan } & : \text { 15 Desember } 2021 \\ \text { Disetujui } & : \text { 2 Januari } 2022 \\ \text { Dipublikasi } & : 8 \text { Januari } 2022\end{array}$

ABSTRACT

This study aims to examine and analyze the effect of financial performance (profitability, liquidity, leverage), dividend policy and managerial ownership on firm value. The population in this study is the consumer goods sub-sector manufacturing companies listed on the Indonesia Stock Exchange (IDX) for the 2016-2020 period as many as 55 companies. Sampling using purposive sampling method, so that the sample obtained as many as 9 companies. This study uses quantitative methods. This study uses secondary data obtained from the web www.idx.co.id. The analytical technique used in this research is to use multiple linear regression analysis. Financial performance is measured using profitability, liquidity, and leverage. The results of the study found that profitability had an effect on firm value in manufacturing companies in the consumer goods sub-sector listed on the Indonesia Stock Exchange (IDX) for the 2016-2020 period. Managerial ownership has an effect on firm value in manufacturing companies in the consumer goods sub-sector listed on the Indonesia Stock Exchange (IDX) for the 2016-2020 period. Meanwhile, liquidity has no effect on firm value in manufacturing companies in the consumer goods sub-sector listed on the Indonesia Stock Exchange (IDX) for the 2016-2020 period. Leverage has no effect on firm value in manufacturing companies in the consumer goods sub-sector listed on the Indonesia Stock Exchange (IDX) for the 2016-2020 period. Dividend policy has no effect on firm value in manufacturing companies in the consumer goods sub-sector listed on the Indonesia Stock Exchange (IDX) for the 2016-2020 period.

Keywords: Financial Performance, Dividend Policy, Managerial Ownership, Firm Value

\section{PENDAHULUAN}

Nilai perusahaan adalah bagian penting bagi investor pada pengambilan keputusan. Investor dapat melihat kualitas kerja perusahaan pada masa depan dengan menggunakan nilai perusahaan. Dimana nilai suatu perusahaan selalu menggunakan nilai harga saham. Apabila nilai saham suatu perusahaan mahal, investor akan mendapatkan laba (Suwardika \& Mustanda, 2017).

Tujuan dari suatu perusahaan yaitu membuat nilai perusahaan semakin meningkat yakni dengan cara menarik minat para investor agar berinvetasi di suatu perusahaan (Pramana \& Mustanda, 2016). Dimana kondisi dan kinerja suatu perusahaan dimasa lalu, sekarang dan prospek periode mendatang dapat digambarkan melalui nilai perusahaan (Astuty, 2017).

NiIai perusahaan ditinjau dengan melihat harga saham, jika harga saham semakin meningkat membuat niIai perusahaan juga tinggi, dapat dikatakan baik serta akan menjadi sinyal positif untuk calon pemegang saham dan terjamin pula kesejahteraannya. Meningkatnya harga saham akan meningkatkan pula kekayaan yang akan didapat oleh pemilik (Atmaja, 2020). Dalam pertimbangan pengambilan keputusan atas ketertarikan penanaman modal pada saat investasi terdapat faktor penentu yaitu niIai perusahaan. Nilai perusahaan diukur dengan Price to Book Value (PBV). Nilai rasio PBV semakin tinggi, dapat berdampak saham yang dijual tidak akan laku karena tidak ada ketertarikan dari pihak investor untuk membeli saham (Dwipayana \& Suaryana, 2016). 
Tinggi rendahnya suatu nilai perusahaan dipengaruhi salah satu faktor yaitu kinerja keuangan (Sianturi, 2020). Dalam mengambil keputusan suatu perusahaaan harus lebih meningkatkan kinerjanya, strategis, lebih konservatif dan analitis mengenai keputusan yang akan dijalankan. Rasio profitabilitas, rasio Iikuiditas, dan rasio Ieverage merupakan termasuk faktor yang mempengaruhi nilai perusahaan (Ndruru et al., 2020).

Kinerja keuangan pada penelitian diukur menggunakan yaitu profitabilitas, likuiditas, dan leverage. Profitabilitas ialah kemampuan perusahaan dalam menghasilkan laba dari tingkat penjualan, modal saham, ataupun asset selama periode tertentu (Holyfil \& Ekadjaja, 2021).

Likuiditas artinya kemampuan suatu perusahaan untuk melunasi hutang jangka pendek perusahaan (Putra Adi \& Lestari, 2016). Leverage ialah rasio yang berfungsi untuk menunjukkan kemampuan perusahaan yaitu aktiva perusahaan dibiayai oleh utang (Hidayat, 2019).

Salah satu yang menjadi faktor mempengaruhi nilai perusahaan ialah kebijakan dividen. Kebijakan dividen yakni kebijakan untuk menciptakan keseimbangan diantara dividen periode sekarang dengan pertumbuhan periode kedepannya dengan memaksimumkan harga saham. Apabila perusahaan mampu membayar dividen untuk para investor membuat harga saham akan tinggi sehingga niIai perusahaan mengalami kenaikan (Pangaribuan et al., 2019).

Kepemilikan manajerial (managerial ownership) merupakan keseimbangan antara kepentingan manajemen dengan pemilik perusahaan yang mana pihak agent akan diberikan kesempatan agar dapat menjadi principaI (pemegang saham) (Tambalean et al., 2018). Suatu perusahaan yang ada kepemilikan manajemen akan membantu mewujudkan tujuan yaitu meningkatkan nilai perusahaan dengan cara kemakmuran para investor. Apabila perusahaan mempunyai kepemilikan manajerial yang semakin meningkat dapat membantu calon pemegang saham untuk menjadi tolak ukur dalam menanam modal karena pihak manajemen dengan pemegang saham mempunyai tujuan yang sama (Lestari et al., 2021).

Beberapa penelitian terdahulu dilakukan oleh Gharaibeh \& Qader (2017), Aggarwal \& Padhan (2017), Yee et al (2018), Lumoly et al (20I8), Hidayat (2019), Mubyarto (2019), Rohmah \& Ahalik (2020), Marhaeningtyas \& Hartono (2020), Holyfil \& Ekadjaja (2021) menunjukan yakni profitabilitas berpengaruh terhadap niIai perusahaan, tetapi hasil tidak sejalan penelitian yaitu Kolamban et aI (2020), Lumbantoruan et aI (2021), Lestari et aI (2021) mengemukakan yakni profitabilitas tidak berpengaruh terhadap niIai perusahaan.

Penelitian Aggarwal \& Padhan (2017), Lumbantoruan et al (2021), Lestari et al (2021) menemukan bahwa Iikuiditas berpengaruh terhadap niIai perusahaan. Akan tetapi hasiI tersebut berbeda dari penelitian Lumoly et al (2018), Holyfil \& Ekadjaja (2021) menemukan yaitu likuiditas tidak berpengaruh terhadap nilai perusahaan.

Kemudian di penelitian Aggarwal \& Padhan (2017), Mubyarto (2019), Kolamban et al (2020), Marhaeningtyas \& Hartono (2020) menunjukan yakni Ieverage berpengaruh terhadap niIai perusahaan, tapi hasiI tidak didukung peneIitian Gharaibeh \& Qader (2017), Hidayat (2019) menemukan bahwa leverage tidak berpengaruh terhadap nilai perusahaan.

Dalam penelitian Nwamaka \& Ezeabasili (2017), Hidayat (2019) menemukan bahwa kebijakan dividen berpengaruh terhadap niIai perusahaan, akan tetapi hasil tidak sesuai penelitian oleh Mubyarto (2019), Rohmah \& Ahalik (2020), Marhaeningtyas \& Hartono (2020), Lestari et al (2021) menyatakan yaitu kebijakan dividen tidak berpengaruh terhadap niIai perusahaan.

Di dalam penelitian Polwitoon \& Tawatnuntachai (2020), Lestari et al (2021), menemukan yaitu kepemilikan manajeriaI berpengaruh terhadap niIai perusahaan. Sedangkan peneIitian dari Rohmah \& Ahalik (2020), Marhaeningtyas \& Hartono (2020), Lumbantoruan et al (2021) menunjukkan yaitu kepemilikan manajerial tidak berpengaruh terhadap nilai perusahaan.

Pentingnya niIai perusahaan bagi investor dan perusahaan, dan terdapat beberapa hasil penelitian terdahulu yang tidak sama dan tidak konsisten, penelitian ini menguji kembali pengaruh kinerja keuangan, kebijakan dividen, dan kepemilikan manajerial terhadap nilai perusahaan.

\section{STUDI LITERATUR}

\section{Pengaruh Kinerja Keuangan (Profitabilitas) Terhadap Nilai Perusahaan}

Suatu kemampuan perusahaan daIam memperoleh keuntungan seIama periode tertentu dari tingkat penjuaIan, modaI saham tertentu, ataupun asset disebut profitabilitas. Tujuan pofitabilitas 
Owner: Riset \& Jurnal Akuntansi

e -ISSN : 2548-9224 |p-ISSN : 2548-7507

Volume 6 Nomor 1, Januari 2022

yaitu menjadi tolak ukur dari kinerja manajemen untuk melihat tingkat efektivitas (Hery et al., 2017: 313). Penelitian oleh Lumoly et aI (2018), Hidayat (2019), Mubyarto (2019), Rohmah \& Ahalik (2020), Marhaeningtyas \& Hartono (2020), Holyfil \& Ekadjaja (2021) yang menunjukkan bahwa profitabilitas berpengaruh terhadap nilai perusahaan.

H1.1: Kinerja keuangan (profitabilitas) berpengaruh terhadap nilai perusahaan.

\section{Pengaruh Kinerja Keuangan (Likuiditas) Terhadap NiIai Perusahaan}

Current ratio (CR) digunakan untuk mengukur rasio likuiditas. Current ratio (CR) menjelaskan seberapa besar hutang lancar dapat dibiayai dari asset lancar (Brigham, E.F. and Houston, 2018: 83). Rasio likuiditas yang semakin tinggi dapat menunjukkan yaitu semakin tinggi pula kemampuan suatu perusahaan untuk membayar kewajiban jangka pendek tepat pada waktunya serta dapat memenuhi operasional perusahaan serta dalam pembagian dividen kepada para investor (Putra \& Lestari, 2019). Penelitian oleh Ndruru et aI (2020), Lumbantoruan et aI (2021), Lestari et al (202I) menunjukan yakni Iikuiditas berpengaruh terhadap nilai perusahaan.

H1.2: Kinerja keuangan (Iikuiditas) berpengaruh terhadap niIai perusahaan.

\section{Pengaruh Kinerja Keuangan (Leverage) Terhadap Nilai Perusahaan}

Leverage ialah rasio leverage yang mengukur seberapa banyak perusahaan dibiayai oleh utang. Dalam mengukur kemampuan perusahaan melunasi kewajiban jangka pendek maupun jangka panjang yaitu menggunakan leverage (Kolamban et al., 2020). Hal ini sejaIan penelitian oleh Mubyarto (2019), Kolamban et al (2020), Marhaeningtyas \& Hartono (2020) menunjukkan yaitu leverage berpengaruh terhadap niIai perusahaan.

H1.3: Kinerja keuangan (Ieverage) berpengaruh terhadap nilai perusahaan.

\section{Pengaruh Kebijakan Dividen Terhadap NiIai Perusahaan}

Pendapat dari Pangaribuan et aI (2019) kebijakan dividen merupakan suatu kebijakan dengan memaksimumkan harga sahama untuk menciptakan keseimbangan diantara dividen periode sekarang dengan perumbuhan periode yang akan datang. Apabila perusahaan mampu memenuhi dividen untuk para pemegang saham maka dapat meningkatkan niIai perusahaan karena harga saham juga semakin tinggi. Kebijakan dividen ialah kebijakan dilakukan oleh perusahaan mengenai keuangan yaitu keuntungan yang didapat apakah nanti akan ada pembagian kepada para pemegang saham atau menjadi laba ditahan (Putra Adi \& Lestari, 2016). Penelitian Nwamaka \& Ezeabasili (2017), Hidayat (2019), Pardiastuti et al (2020) menunjukkan hasil yaitu kebijakan dividen berpengaruh terhadap niIai perusahaan.

$\mathrm{H} 2$ : Kebijakan dividen berpengaruh terhadap niIai perusahaan.

\section{Pengaruh Kepemilikan Manajerial Terhadap NiIai Perusahaan}

Kepemilikan manajerial (managerial ownership) merupakan pihak- pihak manajemen yaitu direktur, komisaris, atau manajer yang secara aktif ikut serta daIam pengambilan keputusan dan mmberikan kesempatan atau peluang untuk dapat mempunyai saham perusahaan (Anita \& Yulianto, 2016). Kepemilikan manajerial (managerial ownership) merupakan keseimbangan antara kepentingan manajemen dengan pemilik perusahan yang mana pihak agent diberikan kesempatan agar menjadi principal (investor) (Tambalean et al., 2018). Suatu perusahaan yang ada kepemilikan manajemen akan membantu mewujudkan tujuan yaitu meningkatkan nilai perusahaan dengan cara kemakmuran para investor. Apabila perusahaan mempunyai kepemilikan manajerial yang semakin meningkat dapat membantu calon pemegang saham untuk menjadi tolak ukur dalam menanam modal karena pihak manajemen dengan pemegang saham mempunyai tujuan yang sama (Lestari et al., 2021). Penelitian Polwitoon \& Tawatnuntachai (2020), Lestari et al (2021) yang menunjukkan hasil yaitu kepemilikan manajeriaI berpengaruh terhadap niIai perusahaan.

H3: Kepemilikan manajerial berpengaruh terhadap nilai perusahaan. 


\section{Kerangka KonseptuaI Penelitian}

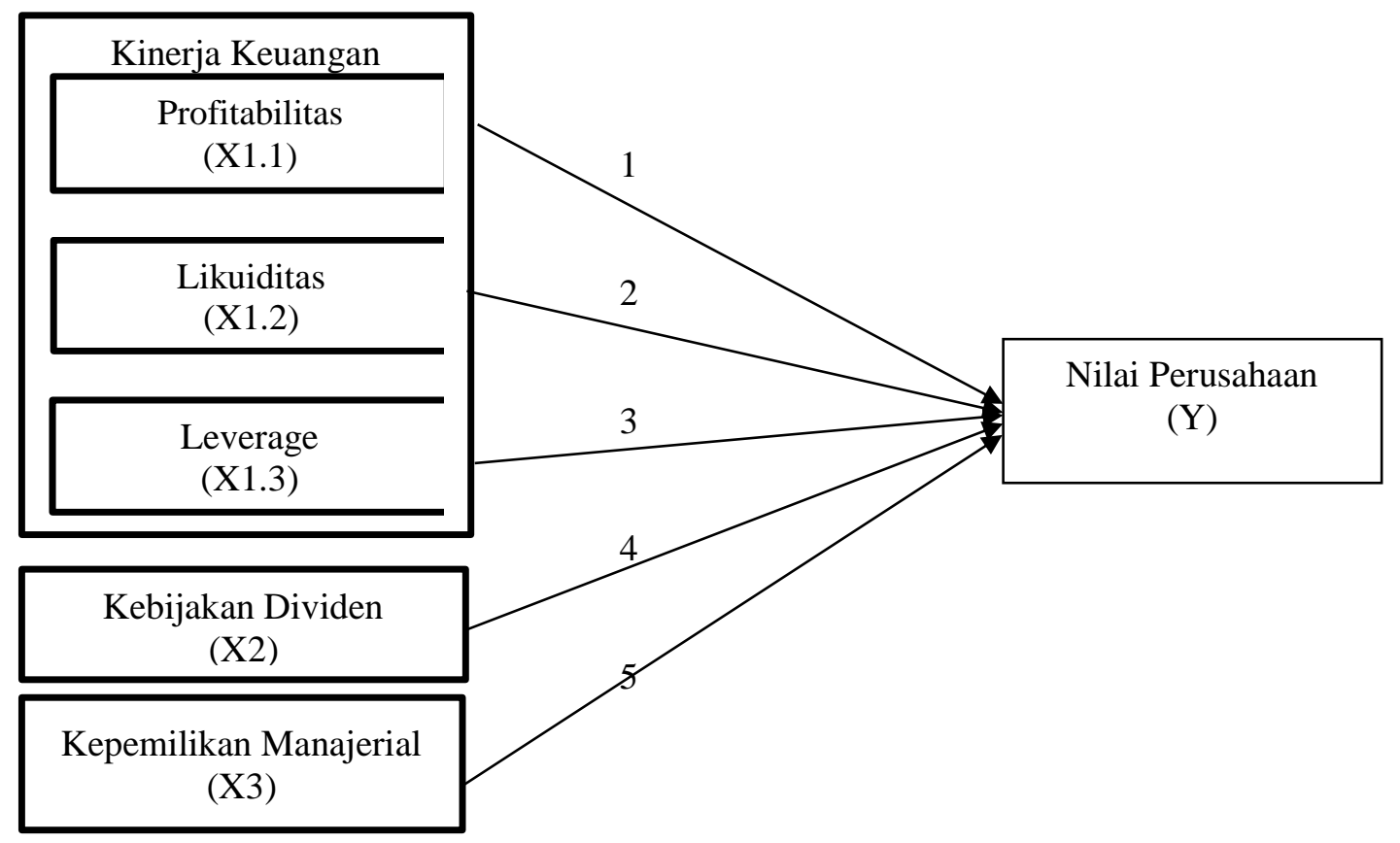

Gamber 1.1 Kerangka Konseptual Penelitian

\section{Metode Penelitian}

\section{METODE}

Jenis penelitian ini berdasarkan pendekatannya merupakan peneIitian kuantitatif. Sumber data dalam riset yaitu data sekunder. Teknik pengumpuIan data yakni dengan teknik dokumentasi pada dokumentasi Iaporan tahunan (AnnuaI Report) dan Iaporan keberIanjutan perusahaan yang terdaftar di Bursa Efek Indonesia melalui website www.idx.com serta website dari perusahaan yang bersangkutan selama periode 20I6-2020. Teknis analisis data penelitian ini menggunakan analisis regresi liniear berganda. PopuIasi riset ini ialah perusahaan manufaktur sub sektor barang konsumsi terdaftar di Bursa Efek Indonesia periode 20I6-2020 dengan diperoleh 55 perusahaan dengan teknik purposive sampIing. Metode analisis data yaitu regresi liniear berganda.

\section{TabeI 4.I}

\section{Kriteria PengambiIan Sampel}


Owner: Riset \& Jurnal Akuntansi

e -ISSN : 2548-9224 |p-ISSN : 2548-7507

Volume 6 Nomor 1, Januari 2022

DOI : https://doi.org/10.33395/owner.v6i1.640

\begin{tabular}{llc}
\hline No & \multicolumn{1}{c}{ Keterangan } & JumIah \\
\hline 1. & $\begin{array}{l}\text { Perusahaan manufaktur } \\
\text { periode 20I6-2020 }\end{array}$ & 55 \\
2. & $\begin{array}{l}\text { Perusahaan manufaktur } \\
\text { di BEI 2016 -2020 }\end{array}$ & $(20)$ \\
3. & Perusahaan yang datanya tidak lengkap periode 20I6-2020 & \\
4. & Perusahaan yang mengalami kerugian & $(18)$ \\
5. Perusahaan yang tidak menggunakan mata uang Rupiah & $(8)$ \\
\hline JumIah sampel perusahaan & 0 \\
JumIah Observasi 9 x 5 Tahun & 9 \\
Data outlier & 45 \\
Jumlah data yang diolah & 3 \\
\hline
\end{tabular}

Sumber: Lampiran 7

\section{Definisi OperasionaI VariabeI}

\section{Variabel Dependen}

Nilai Perusahaan (Y)

NiIai perusahaan ialah persepsi pemegang saham pada tingkat keberhasiIan suatu perusahaan dapat dilihat dari harga saham. Meningkatnya niIai perusahaan akan meningkatkan juga kesejahteraan untuk para pemegang saham (Israel et al., 2018). NiIai perusahaan diukur yaitu Price to Book Value (PBV) merupakan perbandingan diantara harga saham dengan niIai buku per lembar saham. Semakin tinggi PBV dapat meningkatkan pula kepercayaan pasar pada prospek perusahaan serta kesejahteraan yang akan diterima oleh investor pun akan meningkat (Susanti et al., 2018). Berikut rumus Price to Book Value (PBV) yakni:

\section{Variabel Independen (X) \\ Profitabilitas}

$$
P B V=\frac{\text { Harga Per lembar Saham }}{\text { Nilai buku perlembar saham }}
$$

Pofitabilitas adalah rasio proftabilitas untuk mengetahui kemampuan suatu perusahaan untuk mendapatkan keuntungan (Kasmir, 2012). Return on Asset (ROA) ialah rasio untuk menunjukan seberapa kemampuan suatu perusahaan daIam mengeIoIa asset untuk memperoleh keuntungan (Weygandt \& Al, 2019). Perhitungan rasio profitabilitas menggunakan Return on Asset (ROA), berikut rumusnya:

\section{Likuiditas}

$$
\text { ROA }=\frac{\text { Net Income }}{\text { Total Asset }}
$$

Likuiditas iaIah suatu kemampuan perusahaan dalam membayar kewajiban jangka pendek (Pramana \& Mustanda, 2016). Current ratio (CR) merupakan kemampuan suatu perusahaan untuk melunasi kewajiban jangka pendek dengan total asset Iancar perusahaan yang dimiliki (Weygandt \& $\mathrm{Al}, 2019$ ), berikut rumus CR:

\section{Leverage}

$$
\text { CR }=\frac{\text { Current Assets }}{\text { Current Liability }}
$$

Leverage ialah rasio Ieverage digunakan untuk mengetahui seberapa banyak perusahaan dibiayai oleh utang. Perusahaan yang menggunakan utang sangat tinggi dapat membuat perusahaan dalam keadaan yang berbahaya, karena keadaan tersebut perusahaan dapat masuk dalam kategori utang ekstrim (extreme Ieverage). Utang ekstrim (extreme Ieverage) ialah perusahaan yang mempunyai tingkat utang yang terlalu tinggi dan akan kesulitan dalam membayarkan beban utang tersebut (Fahmi, 2015). Berikut menghitung debt to equity ratio (DER) yaitu:

$$
\text { DER }=\frac{\text { Total Debt }}{\text { Total Equiy }}
$$


Owner: Riset \& Jurnal Akuntansi

e-ISSN : 2548-9224 | p-ISSN : 2548-7507

Volume 6 Nomor 1, Januari 2022

DOI : https://doi.org/10.33395/owner.v6i1.640

\section{Kebijakan Dividen}

Kebijakan dividen adalah suatu perusahaan yang mengambil kebijakan mengenai beberapa proporsi dari laba untuk dividen serta laba ditahan (Nurhayati, 2013). Dalam penelitian ini kebijakan dividen diukur menggunakan persentase Iaba bersih yang dibayarkan sebagai dividen tunai atau dividen payout ratio (DPR) (Brigham, E.F. and Houston, 2018: 211). Dengan adanya dividen payout ratio (DPR) dapat menentukan besarnya dividen per lembar saham. Berikut rumus rumusnya:

\section{Kepemilikan Manajerial}

$$
D P R=\frac{\text { Dividen Per Share }}{\text { Earning Per Share }}
$$

Menurut pendapat dari Christiawan \& Tarigan, (2007) kepemilikan manajeriaI merupakan suatu keadaan dimana seorang manajer perusahaan mempunyai saham perusahaan atau dapat dikatakan juga yaitu investor perusahaan. Managerial ownership juga dapat menseimbangkan kepentingan principal dengan agent sehingga hal tersebut diharapkan pada manajemen dapat membantu meningkatkan kinerja di perusahaan. Berikut cara menghitung kepemilikan manajerial yaitu:

$$
\text { Managerial Ownership }=\frac{\text { Jumlah Saham Manajer }}{\text { Jumlah Saham Beredar }}
$$

\section{Hasil Penelitian}

Pengolahan data yakni menggunakan SPSS versi 22 dengan beberapa tahap yaitu:

\section{Statistik Deskriptif}

Tabel 4.4

Hasil Uji Statistik Deskriptif

\begin{tabular}{lccccc}
\hline \multicolumn{1}{c}{ Variabel } & $\mathrm{N}$ & Min & Max & Mean & Std. Deviation \\
\hline Profitabilitas & 42 & 0,014 & 0,167 & 0,09295 & 0,038216 \\
Likuiditas & 42 & 1,013 & 4,844 & 2,71924 & 1,148803 \\
Leverage & 42 & 0,141 & 3,505 & 0,64440 & 0,885761 \\
Kebijakan & 42 & 0,012 & 0,905 & 0,37398 & 0,186495 \\
$\begin{array}{l}\text { Dividen } \\
\text { Kepemilikan }\end{array}$ & 42 & 0,000 & 0,482 & 0,08898 & 0,127799 \\
$\begin{array}{l}\text { Manajerial } \\
\text { Nilai }\end{array}$ & 42 & 0,599 & 68,57 & 2,72000 & 1,804497 \\
$\begin{array}{l}\text { Perusahaan } \\
\text { Valid N } \\
\text { (listwise) }\end{array}$ & 42 & & & & \\
\hline
\end{tabular}

Sumber: Lampiran 7

Pada tabel 4.3 dijelaskan yaitu profitabilitas menunjukkan jumlah $\mathrm{N}$ yang diteliti sebanyak 42 perusahaan. Nilai minimum sebesar 0,014 dan maksimum 0,167 dengan mean sebesar 0,09295 serta standar deviasi sebesar 0,038216. Likuiditas menunjukkan jumlah $\mathrm{N}$ yang diteliti sebanyak 42 perusahaan. NiIai minimum sebesar 1,013 dan maksimum 4,844 dengan mean sebesar 2,71924 serta standar deviasi sebesar 1,148803. Leverage menunjukkan jumlah $\mathrm{N}$ yang diteliti sebanyak 42 perusahaan. Nilai minimum sebesar 0,141 dan maksimum 3,505 dengan mean sebesar 0,64440 serta standar deviasi sebesar 0,885761. Kebijakan dividen menunjukkan jumlah $\mathrm{N}$ yang diteliti sebanyak 42 perusahaan. NiIai minimum sebesar 0,012 dan maksimum 0,905 dengan mean sebesar 0,37398 serta standar deviasi sebesar 0,186495. Kepemilikan manajerial menunjukkan jumlah $\mathrm{N}$ yang diteliti sebanyak 42 perusahaan. NiIai minimum sebesar 0,00dan maksimum 0,482 dengan mean sebesar 0,08898 serta standar deviasi sebesar 0,127799 . NiIai perusahaan menunjukkan jumlah $\mathrm{N}$ yang diteliti sebanyak 42 perusahaan 
Owner: Riset \& Jurnal Akuntansi

e-ISSN : 2548-9224 |p-ISSN : 2548-7507

Volume 6 Nomor 1, Januari 2022

DOI : https://doi.org/10.33395/owner.v6i1.640

dengan nilai minimum sebesar 0,599 dan maksimum sebesar 68,57 dengan nilai mean sebesar 2,72000 sertaIstandarIdeviasi sebesar 1,804497.

\section{Uji Asumsi KIasik}

\section{Uji Normalitas}

Uji normalitas daIam riset ini menggunakan metode One Sample Kolmogrov-Smirnov (K-S). Kriteria dalam pengujiannya yaitu jika p-value > 0,05 berarti residu dinyatakan berdistribusi normaI, namun sebaliknya apabiIa p-value $\geq 0,05$ berarti residu dinyatakan tidak berdistribusi normaI.

Tabel 4.5

One-Sample Kolmogorov-Smirnov Test

\begin{tabular}{|c|c|c|}
\hline & & Unstandardized Residual \\
\hline $\mathrm{N}$ & & 42 \\
\hline & Mean & .0000000 \\
\hline Normal Parameters ${ }^{\mathrm{a}, \mathrm{v}}$ & Std. Deviation & 1.23515389 \\
\hline & Absolute & .108 \\
\hline Most Extreme Differences & Positive & .082 \\
\hline & Negative & -.108 \\
\hline Kolmogorov-Smirnov Z & & .700 \\
\hline Asymp. Sig. (2-tailed) & & .711 \\
\hline
\end{tabular}

a. Test distribution is Normal.

b. Calculated from data.

Pada tabeI 4.5 niIai signifikansi (Asymp.Sig. 2-tailed) yakni 0,711 sehingga disimpuIkan niIai residual berdistribusi normaI dikarenakan memenuhi syarat yaitu niIai signifikansi Iebih dari 0,05 .

\section{Uji Multikoliniearitas}

Penentuan dengan melihat niIai tolerance value $>0,10$ dan niIai VIF $<10$, sehingga dinyatakan tidak terjadi multikolinieritas. Berikut hasil pengujian:

\section{TabeI 4.6}

\section{Hasil Uji Multikolinieritas}

Coefficients $^{\mathrm{a}}$

\begin{tabular}{|c|c|c|c|c|c|c|c|}
\hline \multirow[t]{2}{*}{ Model } & \multicolumn{2}{|c|}{$\begin{array}{l}\text { Unstandardized } \\
\text { Coefficients }\end{array}$} & \multirow{2}{*}{$\begin{array}{l}\text { Standardized } \\
\text { Coefficients } \\
\text { Beta }\end{array}$} & \multirow[t]{2}{*}{$\mathrm{t}$} & \multirow[t]{2}{*}{ Sig. } & \multicolumn{2}{|c|}{$\begin{array}{c}\text { Collinearity } \\
\text { Statistics }\end{array}$} \\
\hline & B & Std. Error & & & & Tolerance & VIF \\
\hline \multirow{6}{*}{$\begin{array}{l}\text { (Constant) } \\
\text { Profitabilitas } \\
\text { Likuiditas } \\
\text { Leverage } \\
\text { Kebijakan } \\
\text { Dividen } \\
\text { Kepemilikan } \\
\text { Manajerial }\end{array}$} & -1.155 & .903 & & -1.280 & .209 & & \\
\hline & 32.336 & 9.434 & .685 & 3.428 & .002 & .326 & 3.067 \\
\hline & -.131 & .295 & -.084 & -.444 & .660 & .368 & 2.717 \\
\hline & -.333 & .346 & -.163 & -.963 & .342 & .451 & 2.215 \\
\hline & 2.719 & 1.540 & .281 & 1.765 & .086 & .513 & 1.948 \\
\hline & 4.768 & 1.969 & .338 & 2.422 & .021 & 669 & 1.494 \\
\hline
\end{tabular}

a. Dependent Variable: Nilai Perusahaan

Dari tabel 4.6 tersebut variabel kinerja keuangan (profitabilitas, likuiditas, Ieverage), kebijakan dividen, dan kepemilikan manajeriaI memenuhi syarat yaitu NiIai ToIerance $>0,1$ dan nilai VIF < 10 sehingga ditarik kesimpuIan yaitu tidak terjadi multikolinearitas. 
Owner: Riset \& Jurnal Akuntansi

e-ISSN : 2548-9224 |p-ISSN : 2548-7507

Volume 6 Nomor 1, Januari 2022

\section{Uji AutokoreIasi}

Ada tidaknya gejaIa autokoreIasi menggunakan metode Durbin-Watson (DW) dengan pengambiIan keputusan angka D-W dibawah -2 berarti ada autokorelasi positif, angka D-W diantara -2 sampai 2 artinya tidak ada autokoreIasi, angka D-W diatas 2 berarti ada autokoreIasi negatif. Berikut hasil pengujiannya:

Tabel 4.7

Hasil Uji Autokorelasi

Model Summary ${ }^{b}$

\begin{tabular}{|c|c|c|c|c|c|}
\hline Model & $\mathrm{R}$ & R Square & $\begin{array}{c}\text { Adjusted R } \\
\text { Square }\end{array}$ & $\begin{array}{l}\text { Std. Error of the } \\
\text { Estimate }\end{array}$ & Durbin-Watson \\
\hline 1 & $.729^{a}$ & .531 & .466 & 1.318141 & .997 \\
\hline
\end{tabular}

a. Predictors: (Constant), Kepemilikan ManajeriaI, Kebijakan Dividen, Leverage, Likuiditas, Profitabilitas

b. Dependent Variable: NiIai Perusahaan

Dari tabel 4.7 diperoleh niIai D yakni 0,997. Menunjukan bahwa nilai DW $(0,997)$ terletak diantara -2 dan $+2(-2<0,997<+2)$, sehingga ditarik kesimpulan yaitu tidak terjadi autokoreIasi.

Uji Heteroskedastisistas

Uji heteroskedastisitas menggunakan metode koreIasi Spearman Rho. Kriteria uji heteroskedastisitas yaitu jika koefisien signifikansi atau sig.(2-tailed) Iebih besar daripada 0,05 sehingga disimpulkan tidak terjadi heteroskedastisitas, apabila koefisien signifikansi atau sig.(2tailed) lebih kecil daripada 0,05 maka dinyatakan terjadi heteroskedastisitas. Hasil uji heteroskedastisistas sebagai berikut:

\section{Tabel 4.8}

Hasil Uji Heteroskedastisitas

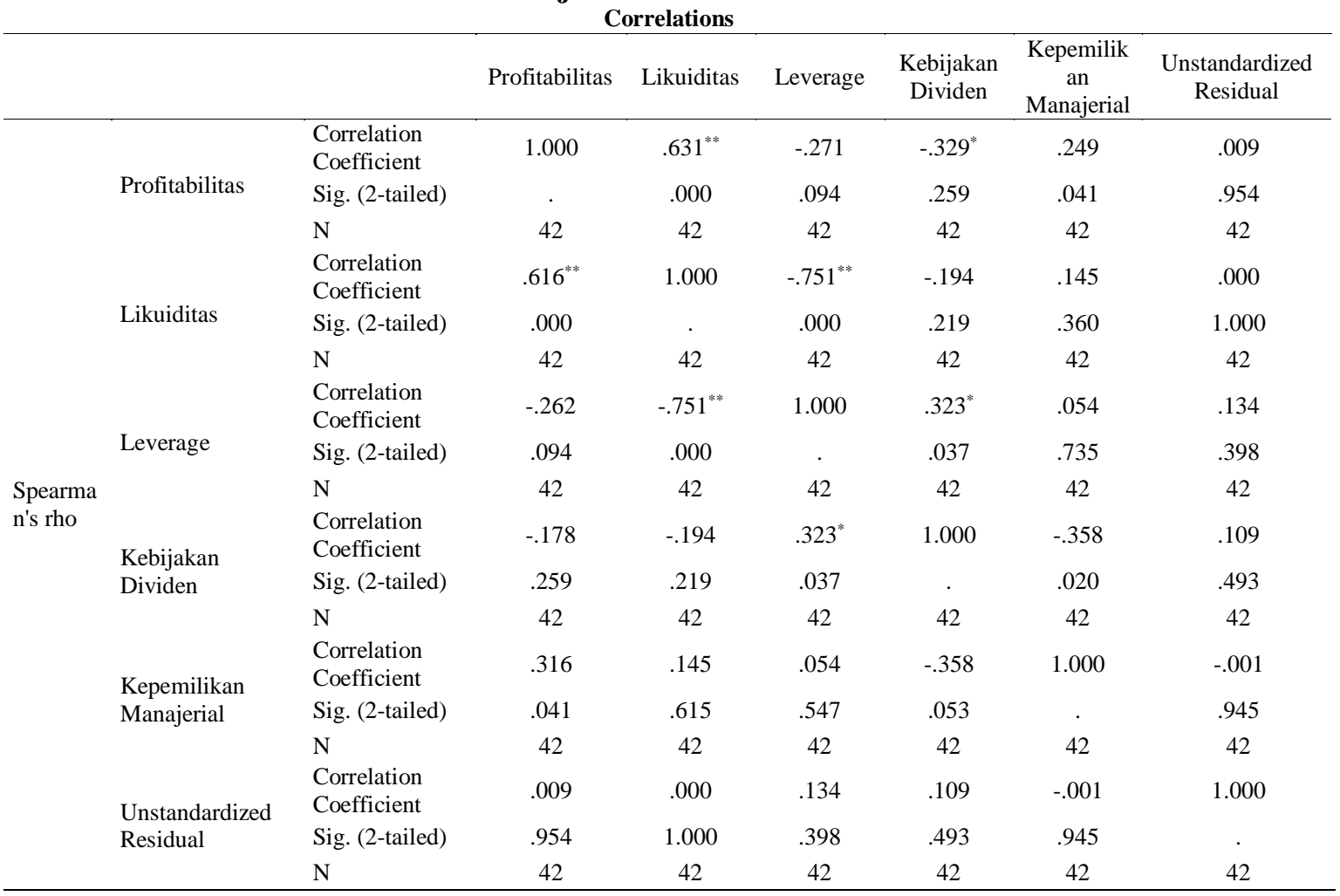

**. Correlation is significant at the 0.01 level (2-tailed).

*. Correlation is significant at the 0.05 level (2-tailed). 
Owner: Riset \& Jurnal Akuntansi

e -ISSN : 2548-9224 |p-ISSN : 2548-7507

Volume 6 Nomor 1, Januari 2022

DOI : https://doi.org/10.33395/owner.v6i1.640

Pada tabel 4.8 menunjukkan yaitu variabel profitabilitas, likuiditas, Ieverage, kebijakan dividen, dan kepemilikan manajeriaI mempunyai sig.(2-tailed) Iebih dari 0,05, sehingga kesimpulannya yaitu tidak terjadi heteroskedastisitas.

\section{Uji Analisis Regresi Linear}

ModeI Regresi

ModeI regresi bertujuan untuk mengetahui apakah ada pengaruh signifikan dari variabeI dependen. Berikut hasil pengujian:

\section{Coefficients $^{\mathrm{a}}$}

\begin{tabular}{|c|c|c|c|c|c|c|}
\hline \multirow{2}{*}{\multicolumn{2}{|c|}{ Model }} & \multicolumn{2}{|c|}{ Unstandardized Coefficients } & \multirow{2}{*}{$\begin{array}{l}\text { Standardized } \\
\text { Coefficients } \\
\text { Beta }\end{array}$} & \multirow[t]{2}{*}{$\mathrm{t}$} & \multirow[t]{2}{*}{ Sig. } \\
\hline & & B & Std. Error & & & \\
\hline \multirow{6}{*}{1} & (Constant) & -1.155 & .903 & & -1.280 & .209 \\
\hline & Profitabilitas & 32.336 & 9.434 & .685 & 3.428 & .002 \\
\hline & Likuiditas & -.131 & .295 & -.084 & -.444 & .660 \\
\hline & Leverage & -.333 & .346 & -.163 & -.963 & .342 \\
\hline & Kebijakan Dividen & 2.719 & 1.540 & .281 & 1.765 & .086 \\
\hline & Kepemilikan & 4.768 & 1.969 & .338 & 2.422 & .021 \\
\hline
\end{tabular}

a. Dependent Variable: Nilai Perusahaan

HasiI uji regresi Iinear berganda diatas dapat ditulis sebagai berikut:

Nilai perusahaan $=(-1,155)+32,336 \mathrm{ROA}-0,131 \mathrm{CR}-0,333 \mathrm{DER}+2,719 \mathrm{DPR}+4,768 \mathrm{KM}$

Persamaan modeI regresi tersebut dapat dijelaskan masing-masing yakni:

1) Nilai konstanta sebesar -1,155, artinya seluruh variabel independen (bebas) yaitu profitabilitas, likuiditas, Ieverage, kebijakan dividen, dan kepemilikan manajerial dianggap konstan atau 0 maka variabel nilai perusahaan akan mengalami penurunan sebesar 1,155 .

2) Nilai profitabilitas sebesar 32,336 artinya apabila setiap kenaikan 1 satuan variabel profitabilitas maka akan meningkatkan nilai perusahaan sebesar 32,336 dengan asumsi variabeI lain tetap.

3) Nilai likuiditas sebesar -0,131 artinya apabila setiap kenaikan 1 satuan variabel likuiditas maka akan mengalami penurunan nilai perusahaan sebesar 0,131 dengan asumsi variabel lain tetap.

4) Nilai leverage sebesar -0,333 artinya apabila setiap kenaikan 1 satuan variabel leverage maka akan penurunan nilai perusahaan sebesar 0,333 dengan asumsi variabel lain tetap.

5) Nilai kebijakan dividen sebesar 2,719 artinya apabila setiap kenaikan 1 satuan variabel kebijakan dividen maka akan meningkatkan nilai perusahaan sebesar 2,719 dengan asumsi variabeI Iain tetap.

6) Nilai kepemilikan manajerial sebesar 4,768 artinya apabila setiap kenaikan 1 satuan variabel kepemilikan manajerial maka akan meningkatkan nilai perusahaan sebesar 4,768 dengan asumsi variabel lain tetap.

\section{Uji KeIayakan ModeI (Uji F)}

Kriteria keputusan apabila $\mathrm{F}$ hitung $>\mathrm{F}$ tabeI atau sig $<0,05$, artinya variabeI independen secara serentak berpengaruh terhadap variabeI dependen dan sebaliknya, yang berarti model regresi fit. Berikut hasil pengujiannya: 
Owner: Riset \& Jurnal Akuntansi

e-ISSN : 2548-9224 | p-ISSN : 2548-7507

Volume 6 Nomor 1, Januari 2022

DOI : https://doi.org/10.33395/owner.v6i1.640

\begin{tabular}{clccccc}
\multicolumn{8}{c}{ ANOVA $^{\mathrm{a}}$} \\
\hline & Model & Sum of Squares & df & Mean Square & F & Sig. \\
\hline \multirow{3}{*}{1} & Regression & 70.955 & 5 & 14.191 & 8.167 & $.000^{\mathrm{b}}$ \\
& Residual & 62.550 & 36 & 1.737 & & \\
& Total & 133.505 & 41 & & & \\
\hline
\end{tabular}

a. Dependent VariabIe: Nilai Perusahaan

b. Predictors: (Constant), Kepemilikan Manajerial, Leverage, Likuiditas, Kebijakan Dividen,

Profitabilitas

Dari uji f diperoleh F hitung $>$ F tabel $(7,998>2,48)$ dan nilai Sig. $<0,05(0,000<0,05)$. Sehingga variabel independen berpengaruh terhadap variabel dependent, berarti kinerja keuangan (profitabilitas, likuiditas, Ieverage), kebijakan dividen, dan kepemilikan manajeriaI terhadap niIai perusahaan.

\section{Uji Hipotesis (Uji t)}

Uji hipotesis (uji t) digunakan apakah variabeI independen berpengaruh terhadap variabeI dependen. Berikut hasil pengujiannya:

Coefficients ${ }^{\mathrm{a}}$

\begin{tabular}{|c|c|c|c|c|c|c|}
\hline \multicolumn{2}{|c|}{ Model } & \multicolumn{2}{|c|}{ Unstandardized Coefficients } & $\begin{array}{c}\text { Standardized } \\
\text { Coefficients } \\
\text { Beta }\end{array}$ & $\mathrm{t}$ & Sig. \\
\hline \multirow{6}{*}{1} & (Constant) & -1.155 & .903 & & -1.280 & .209 \\
\hline & Profitabilitas & 32.336 & 9.434 & .685 & 3.428 & .002 \\
\hline & Likuiditas & -.131 & .295 & -.084 & -.444 & .660 \\
\hline & Leverage & -.333 & .346 & -.163 & -.963 & .342 \\
\hline & Kebijakan Dividen & 2.719 & 1.540 & .281 & 1.765 & .086 \\
\hline & Kepemilikan & 4.768 & 1.969 & .338 & 2.422 & .021 \\
\hline
\end{tabular}

a. Dependent Variable: Nilai Perusahaan

Hasil penelitian uji t dijelaskan:

1) Pengaruh kinerja keuangan (profitabilitas) terhadap nilai perusahaan.

Hipotesis 1.1 yang diajukan dalam penelitian ini adalah kinerja keuangan (profitabilitas) berpengaruh terhadap nilai perusahaan. Berdasarkan hasil pengujian bahwa profitabilitas mempunyai nilai t-hitung sebesar 3,428 dengan diperoleh nilai signifikan sebesar 0,002. Pada penelitian ini t-hitung < t-tabel dan nilai signifikan $<0,05$. Hal ini dapat disimpulkan bahwa profitabilitas berpengaruh terhadap nilai perusahaan. Sehingga dapat dikatakan hipotesis diterima.

2) Pengaruh kinerja keuangan (likuiditas) terhadap niIai perusahaan.

Hipotesis 1.2 yang diajukan dalam penelitian ini adalah kinerja keuangan (likuiditas) berpengarih terhadap nilai perusahaan. Berdasarkan hasil pengujian bahwa likuiditas mempunyai nilai t-hitung sebesar -0,444 dengan diperoleh nilai signifikan sebesar 0,660. Pada penelitian ini t-hitung < t-tabel dan nilai signifikan $>0,05$. Hal ini dapat disimpulkan bahwa likuiditas tidak berpengaruh terhadap nilai perusahaan. Sehingga dapat dikatakan hipotesis ditolak.

3) Pengaruh kinerja keuangan (leverage) terhadap niIai perusahaan

Hipotesis 1.3 yang diajukan dalam penelitian ini adaIah kinerja keuangan (leverage) berpengaruh terhadap nilai perusahaan. Dari hasiI pengujian bahwa leverage mempunyai nilai t-hitung sebesar-0,963 dengan diperoleh niIai signifikan sebesar 0,342. Pada penelitian ini t-hitung > t-tabel dan nilai signifikan >0,05. Hal ini ditarik kesimpulan bahwa leverage tidak berpengaruh terhadap niIai perusahaan. Sehingga dapat dikatakan hipotesis ditolak.

4) Pengaruh kebijakan dividen terhadap niIai perusahaan

Hipotesis 2 yang diajukan dalam penelitian ini adaIah kebijakan dividen berpengaruh terhadap niIai perusahaan. Berdasarkan hasiI pengujian bahwa kebijakan dividen mempunyai nilai t-hitung sebesar 1,765 dengan diperoleh niIai signifikan sebesar 0,086 . Pada penelitian 
Owner: Riset \& Jurnal Akuntansi

e-ISSN : 2548-9224 | p-ISSN : 2548-7507

Volume 6 Nomor 1, Januari 2022

ini t-hitung < t-tabel dan nilai signifikan >0,05. Hal ini ditarik kesimpulan bahwa kebijakan dividen tidak berpengaruh terhadap nilai perusahaan. Sehingga dapat dikatakan hipotesis ditolak.

5) Pengaruh kepemilikan manajeriaI terhadap niIai perusahaan

Hipotesis 3 yang diajukan daIam penelitian ini kepemilikan manajeriaI berpengaruh terhadap niIai perusahaan. Berdasarkan hasil pengujian bahwa kepemiIikan manajeriaI mempunyai niIai t-hitung sebesar 2,422 dengan diperoleh niIai signifikan sebesar 0,021. Pada penelitian ini thitung $>$ t-tabel dan niIai signifikan $<0,05$. Hal ini dapat disimpulkan bahwa kepemilikan manajeriaI berpengaruh terhadap niIai perusahaan. Sehingga dapat dikatakan hipotesis diterima.

\section{Uji Koefisien Determinasi $\left(\mathbf{R}^{2}\right)$}

Digunakan untuk mengukur sumbangan pengaruh jika daIam regresi menggunakan Iebih dari dua variabeI independen. Berikut hasil pengujiannya:

\begin{tabular}{ccccc} 
Model & $\mathrm{R}$ & R Square & $\begin{array}{c}\text { Adjusted R } \\
\text { Square }\end{array}$ & Std. Error of the Estimate \\
\hline 1 & $.729^{\mathrm{a}}$ & .531 & .466 & 1.318141 \\
\hline
\end{tabular}

a. Predictors: (Constant), Kepemilikan Manajerial, Leverage, Likuiditas, Kebijakan Dividen, Profitabilitas

b. Dependent Variable: Nilai Perusahaan

Dari uji koefisien determinasi (R2) menunjukan yaitu niIai Adjusted $R$ Square sebesar 0,466 artinya persentase dipengaruhi oIeh variabeI profitabilitas, Iikuiditas, Ieverage, kebijakan dividen, dan kepemilikan manajeriaI sebesar $46,6 \%$, sedangkan 53,4\% dipengaruhi dari variabeI Iain.

\section{PEMBAHASAN \\ Pengaruh kinerja keuangan (profitabilitas) terhadap nilai perusahaan}

HasiI pengujian menunjukkan yakni kinerja keuangan (profitabilitas) berpengaruh terhadap niIai perusahaan pada perusahaan manufaktur sub sector barang konsumsi yang terdaftar BEI periode 2016-2020. Hal ini membuktikan bahwa besarnya laba yang diperoleh perusahaan dalam menjalankan kegiatan operasionalnya dan dapat meningkatkan nilai perusahan. Perolehan laba yang besar menunjukkan bahwa perusahaan memiliki kinerja yang baik dan memberikan sinyal bahwa perusahaan memiliki prospek yang baik untuk periode mendatang, yang kemudian akan meningkatkan harga saham dan nilai perusahaan. Hasil penelitian ini sejalan dengan Lumoly et al (2018), Hidayat (2019), Holyfil \& Ekadjaja (2021) yang menyatakan bahwa profitabilitas berpengaruh terhadap nilai perusahaan. Namun hasil penelitian tidak sejalan dengan Kolamban et al (2020), Lumbantoruan et al (2021), Lestari et al (2021) menyatakan bahwa profitabilitas tidak berpengaruh terhadap nilai perusahaann.

\section{Pengaruh kinerja keuangan (likuiditas) terhadap niIai perusahaan}

HasiI pengujian menunjukkan yakni kinerja keuangan (likuiditas) tidak berpengaruh terhadap niIai perusahaan pada perusahaan manufaktur sub sector barang konsumsi yang terdaftar BEI periode 2016-2020. Hal ini membuktikan bahwa hubungan antara meningkatnya asset lancar yang dimiliki perusahaan dengan meningkatnya nilai harga saham tidak memiliki keterkaitan.

Sehingga tinggi rendahnya rasio ini tidak mempengaruhi minat investor untuk mengiinvestasikan dananya. Tingginya Iikuiditas perusahaan tidak diikuti dengan meningkatnya nilai perusahaan, karena perusahaan kurang mampu mengelola efektivitas dan efisiensi manajemen kas untuk mengoptimaIkan keuntungan perusahaan. Hasil penelitian ini sejalan dengan penelitian yang dilakukan oleh Lumoly et al (2018), Holyfil \& Ekadjaja (2021) menyatakan bahwa likuiditastidak berpengaruh terhadap nilai perusahaan. Namun hasil penelitian ini tidak sejalan dengan penelitian Lumbantoruan et al (2021), Lestari et al (2021) menyatakan bahwa likuiditas berpengaruh terhadap nilai perusahaan. 
Owner: Riset \& Jurnal Akuntansi

e-ISSN : 2548-9224 | p-ISSN : 2548-7507

Volume 6 Nomor 1, Januari 2022

\section{Pengaruh kinerja keuangan (leverage) terhadap niIai perusahaan}

Hasil pengujian menunjukkan bahwa kinerja keuangan (leverage) tidak berpengaruh terhadap nilai perusahaan pada perusahaan manufaktur sub sector barang konsumsi yang terdaftar BEI periode 2016-2020. Hal ini membuktikan bahwa perusahaan menggunakan modal sendiri untuk mendanai asetnya yang diperoleh dari laba ditahan serta modal saham dibanding mengenakkan hutang. Besar kecilnya hutang yang dimiliki perusahaan tidak terlalu diperhatikan oleh investor, karena para investor melihatnya lebih ke bagaimana pihak manajemen perusahaan menggunakan dana tersebut secara efektif dan efesien untuk mencapai nilai tambah bagi nilai perusahaan. Hasil penelitian ini sejalan dengan Gharaibeh \& Qader (2017), Hidayat (2019) menyatakan bahwa leverage tidak berpengaruh terhadap nilai perusahaan. Namun hasil penelitian ini tidak sejalan dengan Aggarwal \& Padhan (2017), Mubyarto (2019), Kolamban et al (2020), Marhaeningtyas \& Hartono (2020) yang menyatakan bahwa leverage berpengaruh terhadap nilai perusahaan.

\section{Pengaruh kebijakan dividen terhadap niIai perusahaan}

HasiI pengujian menunjukkan bahwa kebijakan dividen tidak berpengaruh terhadap niIai perusahaan pada perusahaan manufaktur sub sector barang konsumsi yang terdaftar BEI periode 2016-2020. Tinggi rendahnya pembagian dividen kepada investor tidak mempengaruhi niIai perusahaan. Karena para investor tidak memperhatikan asal dana tersebut dari keuntungan modaI atau pendapatan dividen, akan tetapi cenderung melihat pengambalian dari investasi. Kesanggupan perusahaan untuk mendapatkan keuntungan yang menjadi pengaruh niIai perusahaan. Sehingga suatu keputusan perusahaan dalam melakukan pembagian dividen atau dijadikan Iaba ditahan tidak berpengaruh terhadap niIai perusahaan.

Hasil penelitian sejalan dengan Mubyarto (2019), Rohmah \& Ahalik (2020) yang menyatakan yaittu kebijakan dividen tidak berpengaruh terhadap niIai perusahaan. Tetapi hasil penelitian ini tidak sejaIan dengan Nwamaka \& Ezeabasili (2017), Hidayat (2019) mengemukakan yaitu kebijakan dividen berpengaruh terhadap niIai perusahaan.

\section{Pengaruh kepemilikan manajerial terhadap nilai perusahaan}

HasiI pengujian menunjukkan bahwa kepemilikan manajeriaI berpengaruh terhadap niIai perusahaan pada perusahaan manufaktur sub sector barang konsumsi yang terdaftar BEI periode 2016-2020. Hal ini terjadi karena manajemen selain pengelola perusahaan juga termasuk pemilik suatu perusahaan yang akan termotivasi untuk meningkatkan kinerja suatu perusahaan. Semakin meningkatnya kinerja suatu perusahaan akan memperoleh laba yang tinggi serta meningkat juga harga saham perusahaan. Sehingga yang mendapatkan keuntungan bukan hanya kepemilikan manajemen tetapi juga seluruh pemegang saham perusahaan.

HasiI penelitian ini sejaIan Polwitoon \& Tawatnuntachai (2020), Lestari et al (2021) mengemukakan yaitu kepemilikan manajeriaI berpengaruh terhadap niIai perusahaan. Tetapi hasiI berbeda dengan Marhaeningtyas \& Hartono (2020), Lumbantoruan et al (2021) yang mengemukakan yakni kepemilikan manajerial tidak berpengaruh terhadap niIai perusahaan.

\section{KESIMPULAN}

PeneIitian ini diIakukan dengan tujuan untuk menguji dan menganalisis pengaruh kinerja keuangan, kebijakan dividen, dan kepemilikan manajerial terhadap nilai perusahaan pada perusahaan manufaktur sub sector barang konsumsi yang terdaftar di BEI periode 2016-2020. Kinerja keuangan diukur menggunakan profitabilitas, likuiditas, dan leverage. Dari hasil penelitian yang telah dilakukan, sehingga ditarik kesimpuIan yaitu profitabilitas dan kepemilikan manajerial berpengaruh terhadap nilai perusahaan. Sedangkan Iikuiditas, levergae, dan kebijakan dividen tidak berpengaruh terhadap niIai perusahaan. Peneliti menyadari ada keterbatasan daIam penelitian ini, yaitu peneIitian ini hanya mengambiI sampeI pada perusahaan manufaktur sub sector barang konsumsi, variabeI penelitian terfokus pada keuangan, kebijakan dividen, dan kepemilikan manajerial dan keterbatasan Iainnya. Saran untuk penelitian selanjutnya Penelitian selanjutnya diharapkan untuk mengambil objek penelitian atau popuIasi penelitian pada seIuruh perusahaan manufaktur terdaftar di BEI, agar dapat digeneralisasikan pada sector Iain, dapat dijadikan pedoman, serta acuan yang Iebih relevan. Penelitian selanjutnya bisa menambahkan variabeI 
Iainnya seperti ukuran perusahaan, struktur modal dan CSR untuk diuji pengaruhnya terhadap niIai perusahaan.

\section{REFERENSI}

Aggarwal, D., \& Padhan, P. C. (2017). Impact of Capital Structure on Firm Value : Evidence from Indian Hospitality Industry. Scientific Research Publishing, 982-1000. https://doi.org/10.4236/tel.2017.74067

Anita, A., \& Yulianto, A. (2016). Pengaruh Kepemilikan Manajerial Dan Kebijakan Dividen Terhadap Nilai Perusahaan. Management Analysis Journal, 5(1), 229-232.

Astuty, P. (2017). The influence of fundamental factors and systematic risk to stock prices on companies listed in the Indonesian stock exchange. European Research Studies Journal, 20(4), 230-240. https://doi.org/10.35808/ersj/830

Atmaja, S. (2020). Faktor-Faktor Yang Mempengaruhi Nilai Perusahaan Di Sektor Pertanian Pada Bursa Efek Indonesia Tahun 2015-2019. Journal Ekonomi dan Bisnis, 1, 1-17.

Brigham, E.F. and Houston, J. (2018). Dasar Dasar Manajemen Keuangan (14th ed). Salemba Empat.

Christiawan, Y. J., \& Tarigan, J. (2007). Kepemilikan Manajerial: Kebijakan Hutang, Kinerja Dan Nilai Perusahaan. Jurnal Akuntansi dan Keuangan, 9(1), 1-8-8. https://doi.org/10.9744/jak.9.1.pp.1-8

Dwipayana, M. A. T., \& Suaryana, I. G. N. A. (2016). Pengaruh Debt To Assets Ratio, Devidend Payout Ratio, Dan Return on Assets Terhadap Nilai Perusahaan. E-Jurnal Akuntansi Universitas Udayana, 17(3), 2008-2035. Diambil dari https://ojs.unud.ac.id/index.php/Akuntansi/article/view/22313/16388

Fahmi, I. (2015). Pengantar Manajemen Keuangan Teori dan Soal Jawab. Bandung: Alfabeta.

Gharaibeh, A. M. O., \& Qader, A. A. A. A. (2017). Factors Influencing Firm Value as Measured by the Tobin's Q : Empirical Evidence from the Saudi Stock Exchange ( TADAWUL ). International Journal of Applied Business and Economic Research, 15(January 2017).

Hery, S.E., M.Si., CRP., RSA., \& CFRM. (2017). Teori Akuntansi Pendekatan Konsep dan Analisis. Jakarta: Grasindo.

Hidayat, W. W. (2019). Pengaruh Ukuran Perusahaan, Return on Equity dan Leverage terhadap Nilai Perusahaan pada Perusahaan Manufaktur di Indonesia. Forum Ekonomi: Jurnal Ekonomi, Manajemen, dan Akuntansi, 21(1), 67-75. Diambil dari http://journal.feb.unmul.ac.id/index.php/Forumekonomi

Holyfil, D., \& Ekadjaja, A. (2021). Pengaruh Profitabilitas, Likuiditas, Ukuran Perusahaan, Dan Corporate Social Responsibility Terhadap Nilai Perusahaan. Jurnal Multiparadigma Akuntansi, 3(2), 497-505.

Israel, C., Mangantar, M., \& Saerang, I. S. (2018). Pengaruh Struktur Modal, Kepemilikan Institusional Dan Ukuran Perusahaan Terhadap Nilai Perusahaan Pada Perusahaan Pertambangan Yang Terdaftar Di Bei. Jurnal EMBA: Jurnal Riset Ekonomi, Manajemen, Bisnis dan Akuntansi, 6(3), 1118-1127. https://doi.org/10.35794/emba.v6i3.20073

Kasmir. (2012). Analisis Laporan Keuangan. Jakarta: PT Raja Grafindo Persada.

Kolamban, D. V., Murni, S., \& Baramuli, D. N. (2020). Analisis Pengaruh Leverage, Profitabilitas Dan Ukuran Perusahaan Terhadap Nilai Perusahaan Pada Industri Perbankan Yang Terdaftar Di Bei Analysis Of The Effect Of Leverage, Profitability And Company Size On Firm Value In The Banking Industry Registered. Jurnal EMBA: Jurnal Riset Ekonomi, Manajemen, Bisnis dan Akuntansi, 8(3), 174-183.

Lestari, K. A., Titisari, K. H., \& Suhendro. (2021). Analisis nilai perusahaan ditinjau dari profitabilitas, likuiditas, struktur modal, kebijakan dividen dan kepemilikan manajerial. Inovasi: Jurnal Ekonomi, Keuangan, dan Manajemen, 17(2), 248-255.

Lumbantoruan, M., Purnasari, N., Hutabarat, Y. S., Sinaga, U. M. M., \& Marpaung, H. R. (2021). Pengaruh Kepemilikan Manajerial, Profitabilitas, Liability, Dan Ukuran Perusahaan Terhadap Nilai Perusahaan Pada Perusahaan Industri Dasar Dan Kimia Yang Terdaftar Di Bursa Efek Indonesia Tahun 2016-2019. Costing:Journal of Economic, Business and Accounting, 5(1), 182-189. 
Lumoly, S., Murni, S., \& Untu, V. N. (2018). Pengaruh Likuiditas, Ukuran Perusahaan Dan Profitabilitas Terhadap Nilai Perusahaan (Studi pada Perusahaan Logam dan Sejenisnya yang Terdaftar di Bursa Efek Indonesia). Jurnal EMBA: Jurnal Riset Ekonomi, Manajemen, Bisnis dan Akuntansi, 6(3), 1108-1117.

Marhaeningtyas, D., \& Hartono, U. (2020). Kepemilikan manajerial, kebijakan dividen, leverage, profitabilitas, ukuran perusahaan, dan nilai perusahaan (studi pada perusahaan pertambangan di indonesia). Jurnal Ilmu Manajemen, 8, 1060-1072.

Mubyarto, N. (2019). Profitabilitas, Ukuran Perusahaan, Leverage, Dan Kebijakan Deviden Sebagai Determinan Atas Nilai Perusahaan. Iltizam Journal Of Shariah Economic Research, $3(2), 1-29$.

Ndruru, M., Silaban, P. B., Sihaloho, J., Manurung, K. M., \& Sipahutar, T. T. U. (2020). Pengaruh Likuiditas, Leverage, Dan Profitabilitas Terhadap Nilai Perusahaan Pada Perusahaan Manufaktur Tahun 2015-2017. Jurnal Ilmiah MEA (Manajemen, Ekonomi, dan Akuntansi), 4(3), 390-405.

Nurhayati, M. (2013). Profitabilitas, Likuiditas Dan Ukuran Perusahaan Pengaruhnya Terhadap Kebijakan Dividen Dan Nilai Perusahaan Sektor Non Jasa. Jurnal Keuangan dan Bisnis, 5(2), 144-153.

Nwamaka, O. C., \& Ezeabasili, P. (2017). Effect of Dividend Policies on Firm Value : Evidence from quoted firms in Nigeria. International Journal of Management Excellence, 8(2), 956967.

Pangaribuan, L. N., Susanti, E., Putri, J. A., \& Sembiring, L. D. (2019). Kebijakan Hutang Dan Kebijakan Dividen Terhadap Nilai Perusahaan Pada Sub Sektor Rokok Yang Terdaftar Di Bursa Efek Indonesia. Financial: Jurnal Akuntansi, 5(2), 80-90.

Pardiastuti, P., Samrotun, Y. C., \& Fajri, R. N. (2020). Faktor-Faktor yang Mempengaruhi Nilai Perusahaan pada Perusahaan Manufaktur Sektor Industri Barang Konsumsi yang Terdaftar di BEI Periode 2016-2018. Owner:Riset dan Jurnal Akuntansi, 4(2), 337. https://doi.org/10.33395/owner.v4i2.210

Polwitoon, S., \& Tawatnuntachai, O. (2020). Revisiting Managerial Ownership and Firm Value in the Absence of Market Forces : Evidence from Singapore and Thailand *. Journal of Asian Finance, Economics and Business, 7(8), 1-13. https://doi.org/10.13106/jafeb.2020.vol7.no8.001

Pramana, I. G. N. A. D., \& Mustanda, I. K. (2016). Pengaruh Profitabilitas Dan Size Terhadap Nilai Perusahaan Dengan Csr Sebagai Variabel Pemoderasi. E-Jurnal Manajemen Unud, 5(1), 561594.

Putra, A. N. D. A., \& Lestari, P. V. (2019). Pengaruh Kebijakan Dividen, Likuiditas, Profitabilitas Dan Ukuran Perusahaan Terhadap Nilai Perusahaan. E-Jurnal Manajemen Universitas Udayana, 8(5), 3275. https://doi.org/10.24843/ejmunud.2019.v08.i05.p25

Putra Adi, N. D., \& Lestari, P. V. (2016). Pengaruh Kebijakan Dividen, Likuiditas, Profitabilitas Dan Ukuran Perusahaan Terhadap Nilai Perusahaan. E-Jurnal Manajemen Unud, 5(7), 40444070.

Rohmah, S., \& Ahalik. (2020). Pengaruh Kebijakan Dividen , Kebijakan Utang , Profitabilitas , Kepemilikan Manajerial, dan Komite Audit terhadap Nilai Perusahaan. Jurnal Online Insan Akuntan, 5(1), 41-56.

Sianturi, M. W. E. (2020). Pengaruh Kinerja Keuangan Terhadap Nilai Perusahaan Manufaktur Sektor Industri Barang Konsumsi di BEI. eJournal Administrasi Bisnis, 8(4), 280-289.

Susanti, Y., Mintarti, S., \& Asmapane, S. (2018). Pengaruh struktur modal, kinerja keuangan perusahaan, ukuran perusahaan dan kualitas auditor eksternal terhadap nilai perusahaan pada perusahaan manufaktur yang terdaftar di bursa efek indonesia. Akuntabel: Jurnal Akuntansi dan Keuangan, 15(1), 1. https://doi.org/10.29264/jakt.v15i1.1924

Suwardika, I. N. A., \& Mustanda, I. K. (2017). Pengaruh Leverage, Ukuran Perusahaan, Pertumbuhan Perusahaan, Dan Profitabilitas Terhadap Nilai Perusahaan Pada Perusahaan Properti. E-Jurnal Manajemen Unud, 6(3), 254488.

Tambalean, F. A. K., Manossoh, H., \& Runtu, T. (2018). Pengaruh Kepemilikan Manajerial Dan Kepemilikan Institusional Terhadap Nilai Perusahaan Pada Perusahaan Sektor Industri 
Owner: Riset \& Jurnal Akuntansi

e-ISSN : 2548-9224 |p-ISSN : 2548-7507

Volume 6 Nomor 1, Januari 2022

Barang Konsumsi Di BEI. Jurnal Riset Akuntansi Going Concern, 13(4), 465-473.

Weygandt, \& Al, E. (2019). Financial Accounting with International Financial Reporting Standards, 4th Edition. USA: John Wiley \& Sons, Inc.

Yee, C. S., Sapiei, N. S., \& Abdullah, M. (2018). Tax Avoidance, Corporate Governance and Firm Value in The Digital Era. Journal of Accounting and Investment, 19(2). https://doi.org/10.18196/jai.190299 